\title{
Financial Management Training for Empowerment of Mosque Youth in Pelawad Village, Serang
}

\author{
Rina Nopianti*1, Prastika Tjeng Suwandi ${ }^{2}$, Leni Triana ${ }^{3}$ \\ ${ }^{1,3}$ Universitas Bina Bangsa, ${ }^{2}$ Universitas Multimedia Nusantara \\ rinanopianti.binabangsa@gmail.com
}

\begin{abstract}
Pelawad Village is one of the villages in the Ciruas sub-district, Serang Regency, where the majority of the population is Muslim. Pelawad Village has eight mosques. In the management of mosque finances, based on preliminary information received from the BKPM (Mosque Youth Communication Board) it has not been carried out properly. Almost all mosques do not yet have a good bookkeeping system. This activity aims to provide simple financial bookkeeping training with the theme Financial Management Training for Empowerment of Mosque Youth. The method used in this community service activity is an action study through a training approach for youth and adolescents in the Pelawad-Ciruas village environment. To make this happen, BKPM has collaborated with several Bina Bangsa University lecturers. The partnership cooperation between BKPM and Abdimas team at Bina Bangsa University is carried out with the following agreements: BKPM is responsible for providing training facilities and infrastructure as well as coordinating training participants. The community service team served as resource persons and provided training materials. This activity has an outcome that must be achieved, namely increasing the ability of mosque-based financial management. The activity was carried out by after isha considering that the participants were mosque administrators and BKPM members who were caretakers of the mosque, and lasted for 3 days while still observing strict health protocols.
\end{abstract}

Keywords: BKPM, financial management, mosque-based

\section{Pemberdayaan Pemuda Masjid di Desa Pelawad, Serang melalui Pelatihan Manajemen Keuangan}

\begin{abstract}
Abstrak
Desa Pelawad adalah salah satu desa yang ada di kecamatan Ciruas Kabupaten Serang, di mana penduduknya mayoritas beragama Islam. Desa Pelawad memiliki delapan masjid. Dalam pengelolaan keuangan masjid, berdasarkan informasi pendahuluan yang diterima dari BKPM (Badan Komunikasi Pemuda Masjid) belum dilakukan dengan baik. Hampir semua masjid belum memiliki sistem pembukuan yang baik. Kegiatan ini bertujuan untuk memberikan pelatihan pembukuan keuangan sederhana dengan tema Pemberdayaan Pemuda Masjid melalui Pelatihan Manajemen Keuangan. Metode yang digunakan dalam kegiatan pengabdian kepada masyarakat ini adalah studi tindakan melalui pendekatan pelatihan yang para pemuda dan remaja di lingkungan desa Pelawad-Ciruas. Untuk mewujudkan hal itu BKPM melakukan kerja sama kemitraan dengan beberapa orang dosen Universitas Bina Bangsa. Kerja sama kemitraan antara BKPM dengan tim Abdimas Universitas Bina Bangsa dilaksanakan dengan kesepakatan-kesepakatan sebagai berikut: BKPM bertanggung jawab dalam penyediaan sarana dan prasarana pelatihan serta mengkoordinasi peserta pelatihan. Tim Abdimas bertugas menjadi nara sumber dan menyediakan materi pelatihan. Kegiatan ini memiliki outcome yang harus dicapai, yakni peningkatan kemampuan manajemen pengelolaan keuangan berbasis masjid. Kegiatan dilaksanakan ba'da isya mengingat pesertanya adalah pengurus masjid dan anggota BKPM yang menjadi pengurus masjid, dan berlangsung selama tiga hari dengan tetap memperhatikan protokol kesehatan yang ketat.
\end{abstract}

Kata Kunci: BKPM, manajemen keuangan, berbasis masjid

\section{INTRODUCTION}

Pelawad Village, Ciruas District, covering an area of approximately 114,520 hectares, includes Pelawad Village and Ciruas Permai Park Complex Blok A, Block B, Block C, Blok D, Block E, Block F, Blok G, Blok H, Blok J, Blok K, Blok L and Blok M, with the following boundaries: a. to the north is bordered by Ranjeng Village, Citerep 
Village and Serang City; b. the east is bordered by Citerep Village and Ranjeng Village; c. to the south by the City of Serang; and D. the west is bordered by the City of Serang.

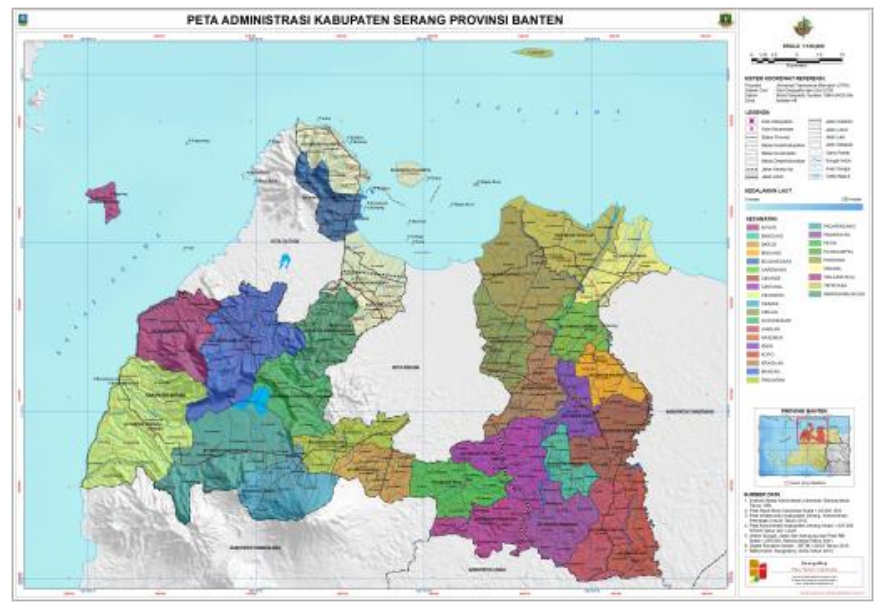

Source: www.bapeda.kabserang.go.id, Accesed 10 April 2021

Figure 1. Map of Serang Regency

The total population is 64,433 , with a population density of $10,685 / \mathrm{km} 2$, the number of Rukun Warga 14 and Rukun Tetangga 67 and 6,870 heads of families (Sumber:Pelawad Village Office). The composition of the population by age is as follows:

Table 1. Total Population by Age

\begin{tabular}{cccc}
\hline Age (year) & Total & Age (year) & Total \\
\hline$<1 \mathrm{~s} / \mathrm{d} \mathrm{5}$ & 13,782 & $31 \mathrm{~s} / \mathrm{d} \mathrm{35}$ & 2,228 \\
$5 \mathrm{~s} / \mathrm{d} 10$ & 12,965 & $36 \mathrm{~s} / \mathrm{d} \mathrm{40}$ & 2,017 \\
$11 \mathrm{~s} / \mathrm{d} \mathrm{15}$ & 12,926 & $41 \mathrm{~s} / \mathrm{d} \mathrm{45}$ & 1,629 \\
$16 \mathrm{~s} / \mathrm{d} 20$ & 8,320 & $46 \mathrm{~s} / \mathrm{d} \mathrm{50}$ & 1,616 \\
$21 \mathrm{~s} / \mathrm{d} 25$ & 2,334 & $51 \mathrm{~s} / \mathrm{d} \mathrm{55}$ & 2,167 \\
$26 \mathrm{~s} / \mathrm{d} \mathrm{30}$ & 1,673 & $>\mathrm{55}$ & 2,776 \\
\hline
\end{tabular}

The population structure can also be grouped based on children, adolescents/youth, adults and parents. Adolescents and youth, namely 11 to 25 years old. Adolescence consists of 2 stages, namely: early adolescence aged 11/12 years - 17/18 years, late adolescence aged 17/18 years - 24/25 years. The large number of youth in Pelawad Village is 13,146 people, which is $36.59 \%$ of the total population of Pelawad Village, if not properly nurtured, it can cause vulnerability to the Pelawad village environment. Criminal acts that have occurred recently in various regions in Indonesia are mostly committed by teenagers and youth. This is where it is hoped that the role of youth organizations in Pelawad Village is to provide guidance and mental education for existing youth. 
Vol. 2, No. 2, July, 2021, pp. $114-120$

e-ISSN: 2722-2004

\section{Financial}

Management

Training for

Empowermen

$\mathrm{t}$ of Mosque

Youth in

Pelawad

Village,

Serang

Rina Nopianti,

P. T. Suwandi, Leni Triana
Table 2. Number of Worship Facilities in Ciruas District in 2019

\begin{tabular}{|c|c|c|c|c|c|}
\hline $\begin{array}{l}\text { Village } \\
\text { (1) }\end{array}$ & $\begin{array}{l}\text { Mosque } \\
\text { (2) }\end{array}$ & $\begin{array}{l}\text { Musholla } \\
\text { (3) }\end{array}$ & $\begin{array}{l}\text { Majlis'talim } \\
\text { (4) }\end{array}$ & $\begin{array}{c}\text { Church } \\
\text { (5) }\end{array}$ & $\begin{array}{c}\text { Others } \\
(6)\end{array}$ \\
\hline 1. Citerep & 5 & 10 & $\ldots$ & - & - \\
\hline 2. Ranjeng & 7 & 18 & ..... & - & - \\
\hline 3. Ciruas & 3 & 4 & ..... & - & - \\
\hline 4. Kadikaran & 4 & - & ..... & - & - \\
\hline 5. Singamerta & 5 & 7 & ..... & - & - \\
\hline 6. Pulo & 7 & 9 & ..... & - & - \\
\hline 7. Gosara & 2 & 3 & ..... & - & - \\
\hline 8. Kepandean & 5 & 6 & ..... & - & - \\
\hline 9. Pamong & 4 & 5 & ..... & - & - \\
\hline 10. Cigelam & 5 & 3 & ..... & - & - \\
\hline 11. Penggalang & 4 & 2 & ..... & - & - \\
\hline 12. Bumijaya & 3 & 4 & ..... & - & - \\
\hline 13. Keserangan & 2 & 9 & ..... & - & - \\
\hline 14. Beberan & 4 & 5 & $\ldots \ldots$ & - & - \\
\hline 15. Pelawad & 8 & 15 & $\ldots \ldots$ & - & - \\
\hline Ciruas & 68 & 100 & $\ldots \ldots$ & - & - \\
\hline
\end{tabular}

The essence of a mosque is a place to carry out all activities related to obedience to Allah alone (Ramli et al., 2014). Therefore, a mosque can be interpreted, not only as a place for prayer and ablution but also as a place to carry out all the activities of the Muslims related to obedience to Allah SWT. The first mosque that was established has carried out ten mosque functions, namely: (1) Places of worship (prayer and zikr), (2) places for consultation and communication (economic, social and cultural issues) ) Place of education, (4) Place for social assistance, (5) Place for military training and preparation of tools, (6) Place for treatment of war victims, (7) Place for peace and dispute court, (8) Hall for receiving guests, ( 9) Places for detention of detainees and (10) centers for information and religious defense (Taufik Hidayat, 2020).

There are 3 types of mosque management that must be carried out, namely (Nariasih et al., 2017):

1. Management and development of facilities, infrastructure and facilities.

All existing facilities, infrastructure and facilities of the mosque must be managed properly and properly used, because it is part of the mandate of the people. In addition, all existing facilities, infrastructure and facilities should be developed in such a way. There are many ways that can be done to carry out the development of mosque facilities and infrastructure, including by means of the following: (a) Adding the number of mosque facilities that are still lacking, (b) Expanding land or space, (c) Improving facilities, facility infrastructure that is still usable, (d) Replacing damaged facilities and infrastructure, (e) Conducting research according to the capabilities and needs in the context of mosque development, (f) Working closely with related parties in order to develop all facilities and infrastructure.

2. Human resource management and development

Three things that underlie the management and development of human resources to be more efficient and effective, namely board meetings, recitation, and regeneration, all of which can be summarized in one activity, namely routine recitation. Apart from routine recitation of human resource management and 
development, training and education for human resources can also be carried out to improve the quality of mosque administrators or managers

3. Management and financial development of mosques

For the financial development of mosques, the following should be carried out: (a) Carrying out productive efforts in accordance with the Sharia, (b) self-help from the people, (c) Developing cooperation through friendship between administrators and / or among mosque congregations.

The mosque is also not free from various problems that must be managed properly. If these various problems are ignored, the existence of the mosque is no different from other buildings. There are 3 problems that mosques often face, namely(Bt Shaharuddin \& Bt Sulaiman, 2015):

1. Closed Management. Managers with a closed leadership style usually do not care about the aspirations of their congregation. They consider themselves more knowledgeable and are indifferent to suggestions and opinions. They find it difficult to accept and treat criticism as constructive input for improvement.

Passive congregations. Passive congregations are also one of the factors inhibiting the progress and prosperity of the mosque. The construction of the mosque will be very choked up if the congregation is reluctant to intervene or is lazy to attend the activities planned by the management.

3. Less activity. The function of the mosque solely as a place of worship for Friday prayers automatically serves the initiative to spur other activities. Mosques like this are far from advanced, let alone prosperous.

One way that can be done in an effort to improve human resources is by conducting education and training (Maulana \& Ridwan, 2020). To achieve the expected performance in an organization or agency, managers must get adequate education and training programs for their positions so that managers are skilled in carrying out their work (Tolulope Femi Oladeji et al., 2016). The meaning of training as follows (Mohd Taib et al., 2016): "Training is a series of activities programmed to increase skills, experience, knowledge, or discussion of individual attitudes".

In this training is also the creation of an environment where people can acquire and learn attitudes, abilities, knowledge skills and specific behavior related to work or job performance. Education is the whole process, technique and teaching and learning method in order to transfer knowledge from one person to another according to predetermined standards. Exercise is a teaching and learning process using certain methods and techniques with the aim of improving the skills and work abilities of a person or group of people (Syamsir, 2015).

One of the mosque-based youth organizations in Pelawad Village is the BKPM (Mosque Youth Communication Board). BKPM is a forum for youth activities from 8 (eight) mosques in Pelawad Village, namely: (1) Arriyad Mosque, (2) AlMukhlisin Mosque, (3) Al-Hidayah Mosque, (4) Syamsul Iman Mosque, (5) Qurrota A'yun Mosque, (6) Al-Hikmah Mosque, (7) Baiturrahman Mosque, (8) Al-Hidayah Mosque. BKPM was established in Pelawad on June 17, 2009. The form of the organization is the Communication Board, a collection of youth organizations and / or youth mosques located in Pelawad Village. BKPM is based on Islam and is based 
Vol. 2, No. 2, July, 2021, pp. $114-120$

e-ISSN: 2722-2004

\section{Financial}

Management

Training for

Empowermen

$t$ of Mosque

Youth in

Pelawad

Village,

Serang

Rina Nopianti,

P. T. Suwandi,

Leni Triana

on the Qur'an and the Sunnah of the Prophet Muhammad SAW. This organization is independent by upholding Ukhuwah Islamiyah and Akhlakul Karimah.

The objective of BKPM is to develop the $d a^{\prime} w a h$ of youth at the Pelawad Village mosque. This goal is achieved by: synergizing the potentials of youth in mosques to strengthen Islamic preaching, increasing the mass of youth and mosque youth who are able to prosper the mosque to support the Islamic revival, and to produce community and nation-based leaders who are mosque-based. BKPM brings together all the Youth of Pelawad Village who make the mosque a center of worship, culture, and a place for the struggle of the ummah and function as a vehicle for fostering aqidah, morals and a means of strengthening the brotherhood of Muslims.

The activities carried out by BKPM include: (1) fostering devotion, faith, and morality of Youth at Pelawad Village Mosque in ways that are in accordance with the Qur'an and the Sunnah of the Prophet Muhammad SAW which is carried out with due regard to the times, (2) explore, develop and solidify all the potential of youth in mosques, both intellectual, scientific and cultural potential which are creative and applicable which will be very useful for the speed of community development, (3) developing cooperation, communication, and brotherhood among youth in village mosques Pelawad with other community members from various backgrounds, both individuals, institutions, associations, government, and the private sector at home and abroad, (4) develop and increase the sensitivity, concern, participation, and solidarity of Youth at the Pelawad Village Mosque towards the problems of fostering the younger generation in the sphere of economy, education, social and culture, (5) other efforts that are lawful and correct according to the Qur'an and Sunnah.

\section{IMPLEMENTATION METHOD}

The steps taken to achieve the targets, targets, goals and desired results are then held to approach and communicate with one of the youth organizations in Pelawad Village, namely BKPM. BKPM conveys and explains the annual work program to the community service lecturer team to find out what programs can be carried out by means of a partnership between BKPM and the community service team. Based on the explanation from BKPM, the partnership cooperation activities to be carried out include providing training in basic accounting and mosque-based financial management. This is because the participants in the training are mostly teenagers and youth at the mosque who are expected to become trustworthy and reliable mosque administrators.

\section{RESULTS AND DISCUSSION Problem Conditions}

The majority of the population in Ciruas District is Muslim. No wonder there are many mosques and prayer rooms scattered in all villages. The total number of mosques in Ciruas District is 68 while the mushola reach 100. In 2019 the number of worship facilities in Ciruas sub-district has not been added. The most number of mosques is in Pelawad Village, 8. The most number of prayer rooms is in Ranjeng Village, 18. In general, mosques and prayer rooms in Ciruas District are still managed by traditional management, where the board of the 
mosque prosperity council is them or their families. or the heirs of those who donate their land / land to become a mosque, so that the expected prosperity of the mosque is not achieved.

\section{Improvement Activities}

Through community service activities with the theme: "Mosque Financial Management Training" it is hoped that it can help direct the mosque youth and mosque administrators in the Pelawad environment to learn how to manage mosque and / or prayer room finances and make good financial reports to the community.
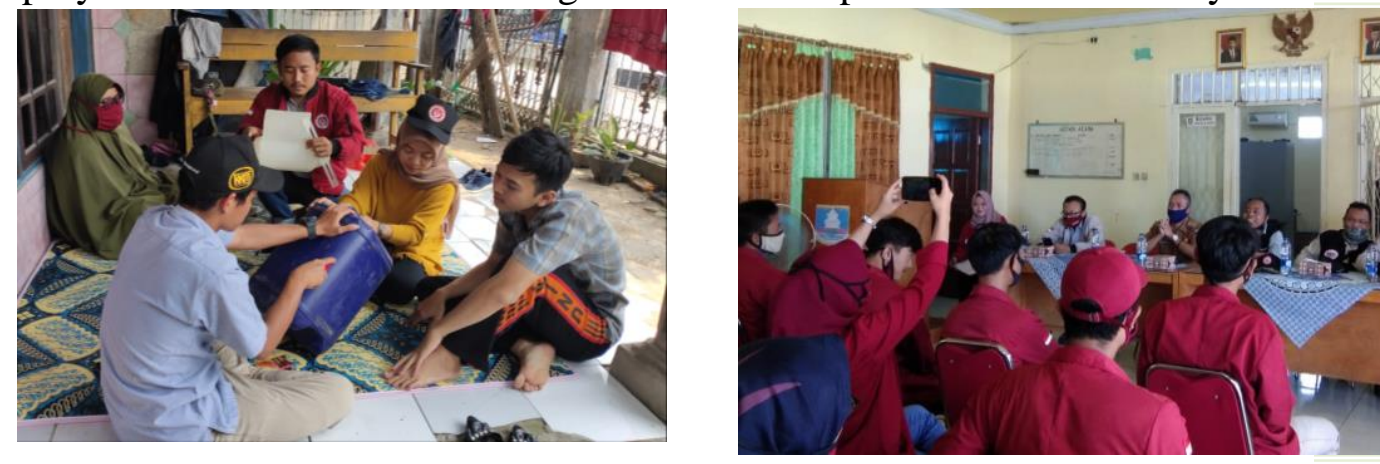

KANGMAS is a journal published by

Neolectura, issued three times in one year. KANGMAS is a scientific publication media in the form of conceptual paper and field research related to social service work. It is hoped that KANGMAS can become a media for academics and esearchers to publish their social service work and become a reference source for the development of social and humanity.

Figure 2. Community Service Activities in Pelawad-Ciruas Village

The results or outputs expected from this activity are:

1. Mosque administrators know well the financial accounting process, starting from the process of recording, grouping revenue and expenditure to the mosque's financial reporting.

2. Mosque administrators know well the types of mosque acceptance and their use, for example the acceptance of zakat fitrah which is mandated by the community/muzakki must be issued out/distributed to those entitled/mustahiq. Another example of receiving Friday boxes is used primarily to pay for Friday worship activities such as transport for preachers, priests, muadzin, etc.

3. Mosque administrators can know very well that the principles of financial management contain the principles of transparency/openness and accountability /honesty, without these it will cause public distrust.

\section{CONCLUSIONS}

BKPM has a work program to improve the quality of mosque youth, mosque administrators and the general public in Pelawad Village. However, they lack experts to implement BKPM programs, for that they collaborate with other organizations such as Bina Bangsa University.

In general, the mosques in Pelawad Village are managed kinship based on the trust of the community. Mosque financial management has not been carried out based on good and correct accounting and financial management principles. The financial recording process, both revenues and expenditures, is carried out in general, no classifications have been made, which sources of funds are excess, and which are expenditures that require large funds.

Suggestions for work partners, in this case BKPM, are that when compiling the annual program, they should have intensive communication with the experts they 
Vol. 2, No. 2, July, 2021, pp. $114-120$

e-ISSN: 2722-2004

\section{Financial}

Management

Training for

Empowermen t of Mosque

\section{Youth in}

\section{Pelawad}

Village,

Serang

Rina Nopianti,

P. T. Suwandi, Leni Triana

need so that these experts can better assist in conducting partnership cooperation. The activities that have been carried out should be followed up by monitoring whether these activities have been implemented by the participants who participated in the activities, in evaluating the implementation of these implementations so that deficiencies can be identified.

\section{BIBLIOGRAPHY}

Bt Shaharuddin, S., \& Bt Sulaiman, M. (2015). Financial Disclosure and Budgetary Practices of Religious Organization: A Study of Qaryah Mosques in Kuala Terengganu. Gadjah Mada International Journal of Business, 17(1), 83. https://doi.org/10.22146/gamaijb.6151

Maulana, A. F., \& Ridwan, R. (2020). Akuntabilitas dan Transparansi Pelaporan keuangan Masjid (Studi Empiris: Masjid Jami' di Kota Banda Aceh). Jurnal Ilmiah Mahasiswa Ekonomi Akuntansi, 5(2), 270-277. https://doi.org/10.24815/jimeka.v5i2.15589

Mohd Taib, M. Z., Ismail, Z., Ahmad, S., \& Rasdi, T. (2016). Mosque Development in Malaysia: Is it the product of evolution and social behaviour? Environment-Behaviour Proceedings Journal, 1(1), 36. https://doi.org/10.21834/e-bpj.v1i1.192

Nariasih, D. Y., Kurrohman, T., \& Andriana, A. (2017). Laporan Keuangan Masjid Berdasarkan Kombinasi PSAK Nomor 45 dan PSAK Nomor 109 (Studi Kasus Pada Masjid XYZ). E-Journal Ekonomi Bisnis Dan Akuntansi, 4(1), 6. https://doi.org/10.19184/ejeba.v4i1.4553

Ramli, A. M., Jalil, A., Hamdan, N., Haris, A., \& Abd Aziz, M. A. (2014). FatwaFatwa Berkaitan Pengurusan Ekonomi dan Kewangan Masjid. https://doi.org/10.12816/0010036

Syamsir, R. (2015). The Economic Empowerment of the Ummah on the Basis of Productive Waqf in West Sumatra, Indonesia. International Journal of Nusantara Islam, 3(1), 31-46. https://doi.org/10.15575/ijni.v3i1.314

Taufik Hidayat, M. R. (2020). Optimalisasi Fungsi Manajemen Dalam Meningkatkan Peran Dan Fungsi Masjid. Tadbir: Jurnal Manajemen Dakwah, 5(3), 285-304. https://doi.org/10.15575/tadbir.v5i3.2106

Tolulope Femi Oladeji, Michael, O. B., \& Victoria Abosede, A. (2016). Comparative Analyses of Strategic Financial Management Practices In Faith-Based and Community-Interest Organisations. Journal of Financial Studies and Research, 1-9. https://doi.org/10.5171/2016.381395 